\title{
Rivers in the making; the definition of "Nahr" as a hybrid watercourse based on geoarchaeological evidence from Southwestern Iran
}

\author{
Elnaz Rashidian ${ }^{1,2}$ (D)
}

Received: 10 August 2020 / Accepted: 8 June 2021 / Published online: 21 June 2021

(c) The Author(s) 2021

\begin{abstract}
This paper explores a new perspective to study the settlement dynamics of riverine landscapes by addressing human-environment interaction in the Ancient Near East through integration of remote sensing, new geodata, and developing a definition of a new category of a watercourse. The complex and entangled network of watercourses in the archaeologically crucial region of southwestern Iran, the Greater Susiana, hinders a clear view of the spatial relations between ancient settlements and their respective environments. The watercourses are known to be of either natural (rivers) or anthropogenic (canals) origin. However, many current watercourses do not fit into either category, which causes misinterpretations of the archaeological record. This paper introduces a third category, which consists of a hybrid of the two existing categories and suggests using the term "Nahr" to address such watercourses. The author implements this idea to a case study, Nahr-e Atiq, a watercourse in north Susiana, which passes two prominent sites, Abu Fanduweh and Haft Tappeh. Based on the results of a geoarchaeological investigation(including a survey, eight sediment cores, and several soil profiles, as well as 58 known archaeological sites), several hydro-morphologic elements are presented for identifying Nahrs. These include sedimentation, morphology, and physical characteristics. The most crucial aspect is the biography of a Nahr, as these hybrid watercourses might consist of different sections with different genesis. The author argues that Nahr, as defined here, must be considered an artifact, and studied as such in the landscape archaeology of the Ancient Near East.
\end{abstract}

Keywords Iran · Ancient Near East · Susiana - Geoarchaeology · Ancient watercourses · Nahr-e Atiq

Elnaz Rashidian

elnaz.rashidian@gmail.com; elnaz.rashidian-nejad@uni-konstanz.de; elnaz.rashidian@imbe.fr

1 University of Konstanz, Konstanz, Germany

2 University Aix-Marseille, Marseille, France 


\section{Introduction: Nahr as a hybrid watercourse}

Watercourses were decisive in the spatial evolution of ancient settlement systems, at least since the early Neolithic. Riverine landscapes were home to prehistoric settlement systems. They provided a suitable geographical setting for the emergence of the first city-states in the Ancient Near East (see Wilkinson (2003) for a description of the prehistoric landscape; see Heyvaert et al. (2010) for a reconstruction of the landscape in lower Susiana; see Lees and Falcon (1952) for geoarchaeological evidence of paleo-landscapes of the area; see Potts (ed.), 2012 for an introduction to different areas and archaeological periods). Therefore, these watercourses must be studied as indispensable actors in the human-environment-network and considered actively in the successive interaction of landscapes and settlements.

Watercourses are not static features in the landscape. Their raison d'etre is of utmost importance in their study as geo-factors in an archaeological setting. The genesis of a watercourse greatly affects the dynamics of the settlement system and its evolution. Therefore, the definition of watercourses based on their genesis is essential when concerning them in their surrounding archaeological landscape(s). We know of two types of watercourses based on their genesis: natural watercourses, such as rivers and streams, and anthropogenic watercourses, such as canals and drainages. Yet not all the watercourses fit into these two categories without any doubt. The definitions seem to be incomplete in terms of covering all watercourses that are encountered in the archaeological record.

Therefore, this paper has two aims: (i) providing a framework for a better definition of watercourses as environmental factors in the context of ancient settlement systems based on the geoarchaeological evidence; and (ii) implementing this definition in a case study in southwestern Iran for further refining of the concept in the Ancient Near East. Here, the term "Nahr" will be presented to refer to a hybrid watercourse in the context of the Greater Susiana. ${ }^{1}$

The Greater Susiana is the archaeological term for the area between the Zagros mountains in the northwest and the Persian Gulf in the south, neighboring the south Mesopotamian plains in the west and the Dehloran plains in the north (see Wilkinson (2012) for an outline on the physical landscape of the area). It correlates roughly with the modern province of Khuzestan in southwestern Iran (see Fig. 1 for the study area). The archaeological richness of this region provides a solid framework to work out and test the human-environment-interaction-related hypothesis based on geoarchaeological evidence (see Moghaddam (2012) for an outline of the archaeology of the area).

Besides the great rivers such as Euphrates and Tigris in Mesopotamia, and Karun, Dez, and Karkheh in Susiana, the region includes several tributaries and smaller rivers, as well as an impressive network of artificial canals of ancient age. These networks of watercourses are very much entangled, to a degree that makes it almost impossible to differentiate specific watercourses and their genesis on the ground. This fact presents a problem in

\footnotetext{
1 There are similar terms in this regard, which have been excluded due to their established use in the discourse. A few examples follow: Stream is a small and narrow river, waterway is a navigable watercourse, channel is a length of water wider than a strait which connects two larger areas of water, drainage is a canal with the function of removing excess water from the surface of the land, watercourse is any channel of water independent of its genesis, river is a large natural stream of water flowing in a channel towards a body of water with a delta. Therefore, none of these terms are suitable for the aim of this paper (thanks to an anonymous reviewer for suggesting explaining the reasons for choosing the term Nahr and avoiding confusion).
} 
archaeological investigations in this region and deems an evidence-based categorization of watercourses necessary.

Recently, the crucial importance of distinguishing between natural rivers and humanmade canals in their archaeological context has been emphasized. Based on his investigation on Mesopotamian landscape archaeology, Jotheri (2018) has identified seven key differences between the two types of watercourses: topographical cross-sections, crevasse splays, marshes, meandering, cut-offs, and oxbow lakes, channel patterns, and stream directions (Jotheri 2018, p. 111). The geomorphological differences that he identified in natural and anthropogenic watercourses can lead to a better identification of canals in Mesopotamia. Jotheri states that canal levees are narrow and have a steep slope, are dug in a flat area, generally dug at a possible crevasse splay, build no associative marshes or oxbow lakes, have a lower sinuosity, e.g., are less meandering, and do not always follow the general slope of the plain (114-119). Applying these rules to our case study (see Fig. 2), Atiq meets all the criteria for a canal.

Yet, there is evidence for canals, that are shaped like natural rivers, but can become canals with further manipulation. Jotheri (2018) mentions the Hindiya canal in south Mesopotamia (118, Fig. 6.8.) and shows its characters as both canal and meandering river. This very example of ambivalence makes it clear that we need further data and a more detailed categorization of watercourses in the ancient Near East.

$\mathrm{Nahr}^{2}$ is a known term for rivulets in Persian, Arabic, Hebrew, Urdu, and Hindi, meaning "running water" (Bosworth and Burton Page 2012). Numerous canals and streams are called Nahr in southwestern Iran and southern Iraq, where prominent excavated archaeological sites of the Near East are located (see Verkinderen (2015) for their locations and historical context in south Mesopotamia and Lower Susiana). Therefore, this term can be used to categorize a specific type of watercourse in this region, besides the two common terms, river, and canal. Below, I will illustrate the usefulness of this new term for certain watercourses.

\section{Methods of investigation}

Anyone with first-hand experience in field archaeology of the ancient Near East is aware of the confusing web of watercourses in their study area, which hinders a comprehensive reconnaissance of the settlement patterns and their relevant water management. This challenge is not to be mastered relying solely on archaeological methods; rather, geoarchaeological investigations are the key.

Therefore, a bottom-up methodology has been established to produce reliable data on one case study and provide a hypothesis based on this example. A combination of sources has been studied first: historical accounts and archaeological reports. The former source consists of travel diaries, descriptions from the Middle Ages, confidential reports from the European spies from the eighteenth and nineteenth centuries, and reports of agricultural projects from the twentieth century. The latter consists of reports regarding the excavations of Susa, Haft Tappeh, Abu Fanduweh, and their environs. Analog maps and geo-elements of these sources have been digitalized and georeferenced in the ArcGIS environment (standard version for desktop 10.6.).

\footnotetext{
${ }^{2}$ Writing in Persian and Arabic:
} 


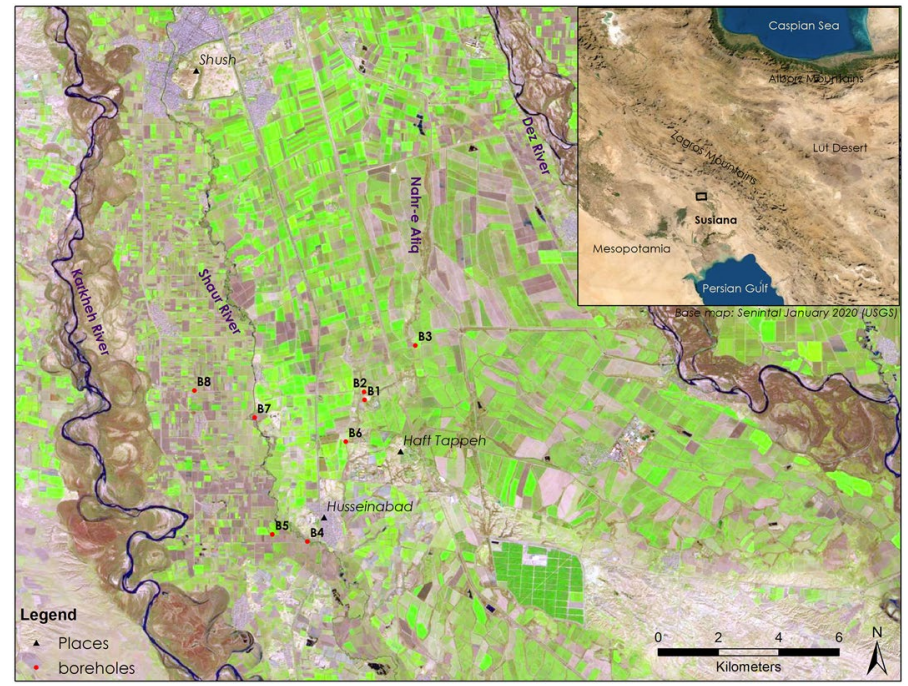

Fig. 1 Map of the study area, rectangle in the insect map shows the study area (see Table 2 for key data on the cores)

Based on published data, archaeological sites in the vicinity of the case study were identified, categorized in their relative chronologies, and integrated into the spatial data in GIS. This step has enabled a chronological framework for the analysis of different sections of the watercourse and its cultural setting throughout the last millennia.

As the second step, georeferenced data have been integrated into available imagery ${ }^{3}$ (see Table 1), including declassified Corona imagery from 1968, current available imagery via Google Earth, and elevation models via ArcGIS online (Standard license for personal use). Spatial analysis and raster calculations have been conducted to produce the figures presented in this paper.

Besides imagery, various layers of soil data have been integrated into the geo-database. These include soil classes available via World Soil Information(ISRIC) ${ }^{4}$ and obtained through the Geographical Survey of Iran (GSI).

The third step was to obtain original data to refine the available datasets. Relevant data produced during a geoarchaeological survey, including a stratified sampling survey by the author in 2014, were then studied to gain a detailed view of the case study and its environs. The data consists of eight sediment cores, ranging in depth from 3 to $7 \mathrm{~m}$ below the surface, which have been produced using a mechanical vibercorer (model Cobra) in the period between October to November 2014 (see Fig. 1 and Table 2 for locations).

The cores were examined in an on-site lab using a ProScope with $15 \times$ magnification and were lithologically described (see Figs. 3, 4, 5, and 6 for the cores) and sampled for further analysis. Laboratory analyses were also conducted in the geoscience laboratory of the Goethe-university of Frankfurt between February and April 2015 by the author.

\footnotetext{
3 Mostly obtained from the USGS database in 2017, and purchased from the Iranian Geographical survey in 2015 .

4 International Soil Reference and Information Centre.
} 


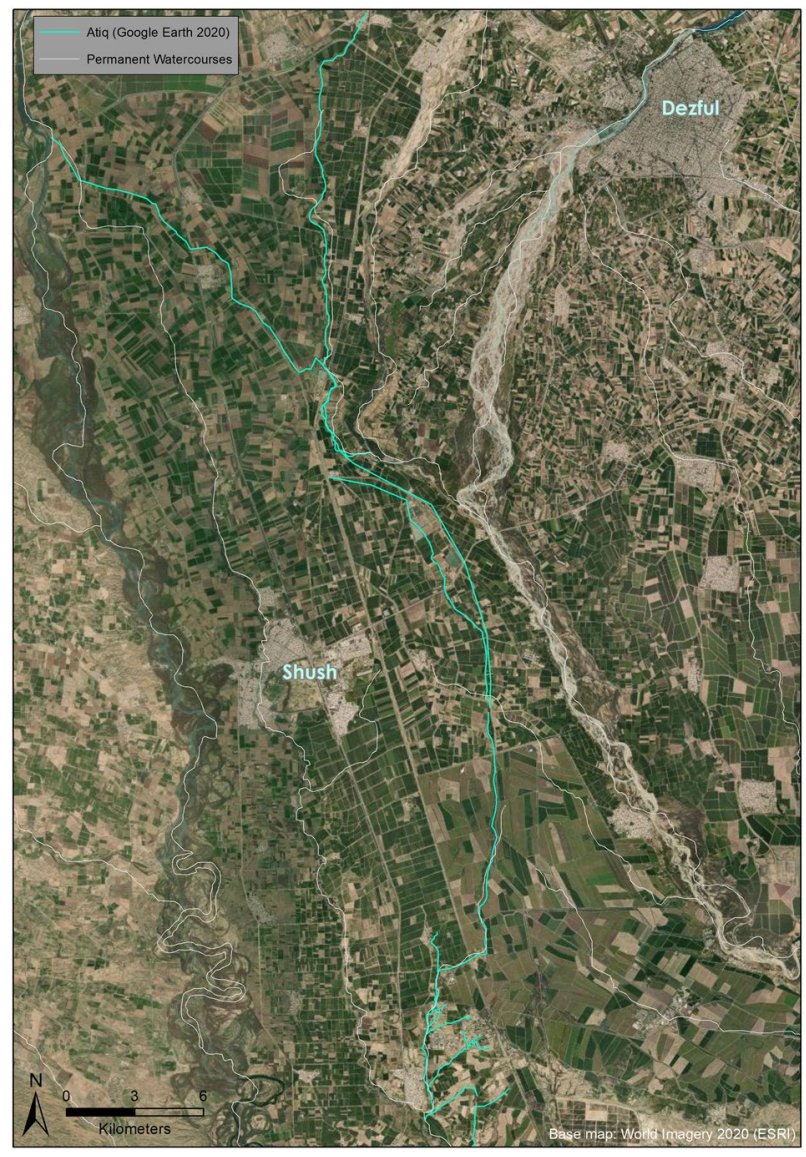

Fig. 2 The current course of Nahr-e Atiq in southwestern Iran visible on Google Earth imagery

The samples were analyzed for $\mathrm{pH}$, electrical conductivity (EC), particle size distribution (via laser diffraction method), organic matter, inorganic carbon content, and soil type. Based on the particle size distribution, sorting degree, soil formation processes, and finally, the genesis of each soil sample was estimated. These results are presented (see Table 2) and discussed in this paper.

The study of the cores provided original data regarding the sedimentation of the watercourse in the case study and enabled to establish a hypothetical sketch of its evolution for further discussion. The locations of cores (boreholes) were selected to encompass fluvial horizons of both natural rivulets and known artificial canals. This has enabled a quantitative comparison of sedimentation and soil formation processes and highlighted probable differences among the two types of watercourses.

As the fourth step, a spatial analysis was conducted to identify the physical characters of the case study and their genesis. This resulted in identification of a mosaic of natural and anthropogenic features in one rather small watercourse and highlighted the necessity of defining a third category for watercourses, based on their genesis. 
Table 1 List of imagery data used in the current analysis

\begin{tabular}{llll}
\hline Imagery data & Date & Source & Code \\
\hline CORONA declassified & 18 Feb 1968 & USGS & CR68 \\
SPOT (tile n33e048) & 15 Mar 1986 & USGS & SP86 \\
Radar SIR-C & 18 Apr 1994 & USGS & RDS94 \\
Sentinel void filled & 28 Mar 2019 & USGS & SNv19 \\
SRTM Arc & 06 Sep 2014 & USGS & Sra14 \\
Land Sat & 31 Dec 2004 & Google Earth & LN04 \\
Land Sat & 31 Dec 1986 & Google Earth & LN86 \\
Land Sat & 31 Dec 2002 & Google Earth & LN02 \\
\hline
\end{tabular}

Table 2 Key data on the boreholes/cores mentioned in this paper

\begin{tabular}{|c|c|c|c|c|c|}
\hline Name & Elevation (m) & Depth (m) & Location & & Date of sampling \\
\hline B1 & 70 & 3 & $32^{\circ} 5^{\prime} 35.07^{\prime \prime} \mathrm{N}$ & $48^{\circ} 18^{\prime} 55.94^{\prime \prime} \mathrm{E}$ & 28.10 .2014 \\
\hline B2 & 62.3 & 6 & $32^{\circ} 5^{\prime} 43.57^{\prime \prime} \mathrm{N}$ & $48^{\circ} 18^{\prime} 54.75^{\prime \prime} \mathrm{E}$ & 1.11 .2014 \\
\hline B3 & 63.5 & 7 & $32^{\circ} 06^{\prime} 35.0^{\prime \prime} \mathrm{N}$ & $48^{\circ} 19^{\prime} 58.37^{\prime \prime} \mathrm{E}$ & 11.11 .2014 \\
\hline B4 & 41.1 & 5 & $32^{\circ} 3^{\prime} 1.13^{\prime \prime} \mathrm{N}$ & $48^{\circ} 17^{\prime} 48.25^{\prime \prime} \mathrm{E}$ & 11.11 .2014 \\
\hline B5 & 41.3 & 5 & $32^{\circ} 3^{\prime} 7.82^{\prime \prime} \mathrm{N}$ & $48^{\circ} 17^{\prime} 3.59^{\prime \prime} \mathrm{E}$ & 12.11 .2014 \\
\hline B6 & 53.7 & 7 & $32^{\circ} 4^{\prime} 49.58^{\prime \prime} \mathrm{N}$ & $48^{\circ} 18^{\prime} 33.60^{\prime \prime} \mathrm{E}$ & 22.11 .2014 \\
\hline B7 & 43.4 & 3 & $32^{\circ} 5^{\prime} 12.97^{\prime \prime} \mathrm{N}$ & $48^{\circ} 16^{\prime} 37.41^{\prime \prime} \mathrm{E}$ & 22.11 .2014 \\
\hline B8 & 45.1 & 4 & $32^{\circ} 5^{\prime} 40.54^{\prime \prime} \mathrm{N}$ & $48^{\circ} 15^{\prime} 20.48^{\prime \prime} \mathrm{E}$ & 22.11 .2014 \\
\hline
\end{tabular}

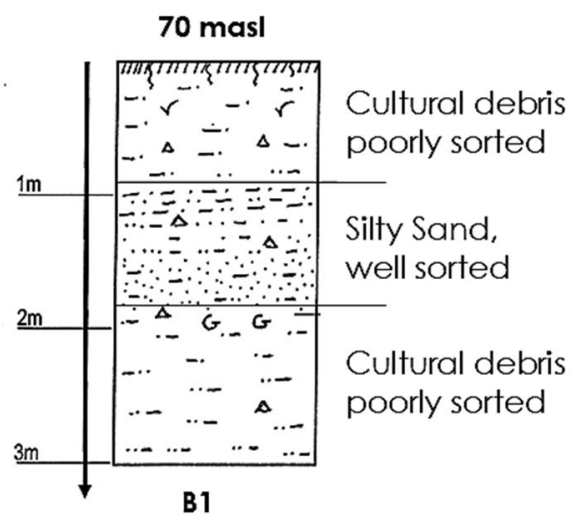

\begin{tabular}{|c|c|}
\hline & Legend \\
\hline & Sand \\
\hline 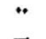 & Silt \\
\hline- & Clay \\
\hline$-r$ & Loam \\
\hline$=$ & Compact clay \\
\hline$x$ & Oxidation \\
\hline$G$ & $\begin{array}{l}\text { Reduction } \\
\text { Peat }\end{array}$ \\
\hline 00 & Gravel \\
\hline$\Delta$ & Ceramics \\
\hline$y$ & Vegetation \\
\hline 5 & Roots \\
\hline$\pi$ & Humus \\
\hline घ & Stone / Bricks \\
\hline () & Mollusca \\
\hline
\end{tabular}

Fig. 3 Schematic view of B1 (illustrated by the author) 


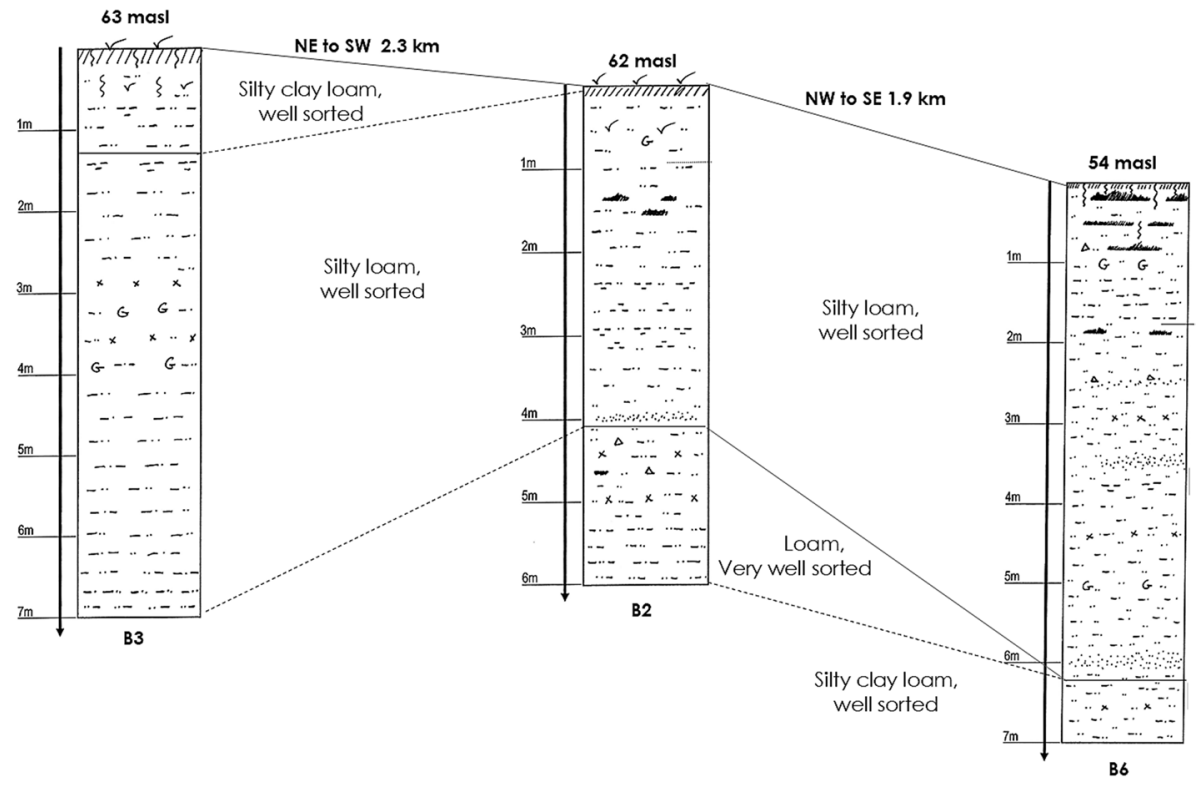

Fig. 4 Schematic view of B2, B3, and B6 (illustrated by the author)

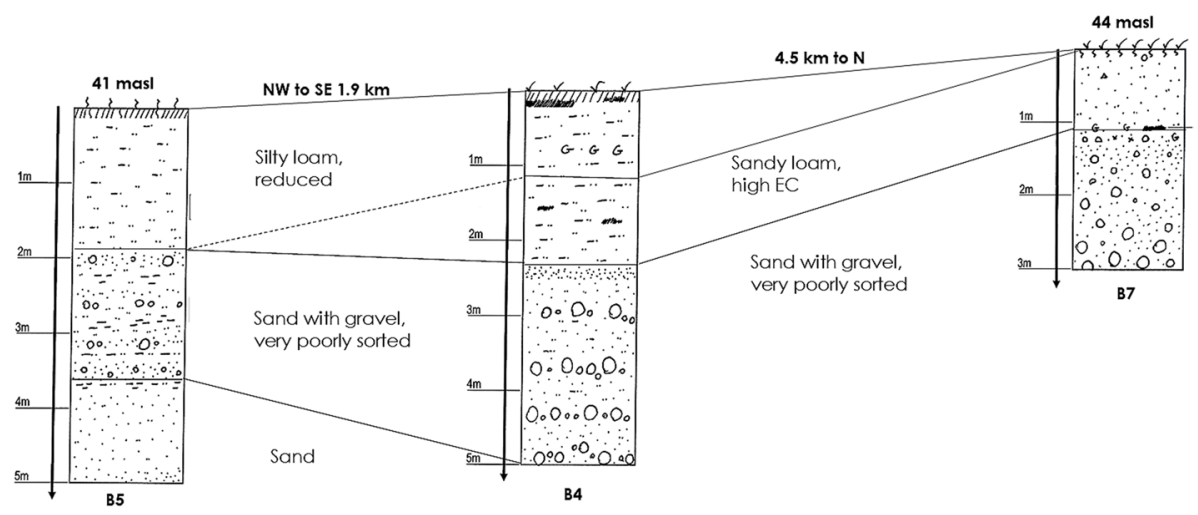

Fig. 5 Schematic view of B4, B5, and B7 (illustrated by the author)

\section{Case study: Nahr-e Atiq}

It is safe to assume that the palaeo-landscape of the Greater Susiana has undergone a series of drastic as well as gradual changes, both of natural and anthropogenic causes, resulting in its evolution towards its modern state (Alizadeh et al. 2004; Barthold 1984; Gasche 2005; Hansman 1970; Heyvaert et al. 2010; Verkinderen 2015; Woodbridge 2013). Recent geomorphological investigations have confirmed rather moderate and ongoing earth surface movements $\left(0.19-2.26 \mathrm{~mm} / \mathrm{year}^{-1}\right)$ due to tectonic activities in the upper Susiana plains (Woodbridge 2013, p. 198). This has certainly led to the uplifting of the anticlines and the incision of the rivers. 


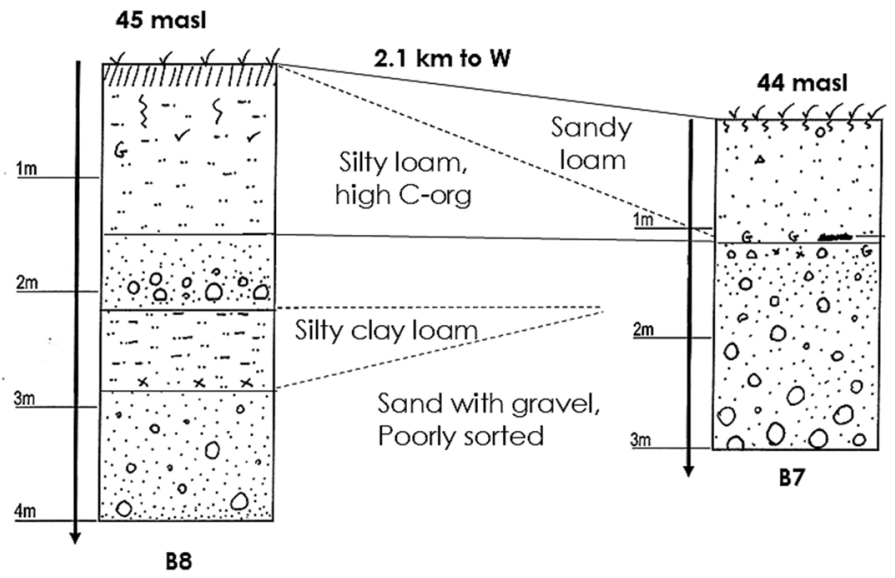

Fig. 6 Schematic view of B7 and B8 (illustrated by the author)

The Karkheh River is considered to be the most crucial watercourse shaping the ancient settlement patterns of the western Susiana plains (Ehlers 2011). Yet, a recent geoarchaeological study (Sarafi et al. 2019) has suggested that the Dez River was indeed a player in this regard, providing water through canals to the whole area between the Dez and Karkheh floodplains. The study suggests that a geomorphologic event (excessive erosion?) has led to the lowering of water levels and cutting out its canals sometime in the first millennium CE. ${ }^{5}$ Probably, following this event, the agricultural and settlement system of the area had to be reorganized. This might be the reason behind the emergence of the Harmushi canal from Karkheh (Sarafi et al. 2019, p. 29). However, the incision of the Susiana riverbeds in the mid-Holocene has already been known since the 1960s (Veenenbos 1958, p. 41).

Currently, the traces of ancient canals between Dez and Karkheh cannot be found in a complete form. These canals were even navigated in the nineteenth century (British Military 1924, p. 234). In the mid-twentieth century, they were still visibly traceable from the rivers for a few kilometers into the arable fields before they suddenly disappeared in the landscape (Veenenbos 1958, p. 55). It is clear that this area has seen intensive manipulation of water systems since at least the first millennium BCE. The extensive construction of canals in Late Antiquity (Arsacid/Parthian and Sassanian times) has led to a mosaic of canal traces which cut and cross each other subsequently. Furthermore, the area has undergone an agricultural renaissance in Medieval times (Middle Islamic period), as the historians of the tenth century CE report (see Verkinderen (2015) for a detailed account).

Finally, large scale projects since the mid-twentieth century-such as the Dez irrigation project and the Haft Tappeh sugarcane plantation-have reshaped the surface water networks anew. Besides, it has been suggested that a series of available canals have been revived and re-joined during later construction, so that current canals are extremely incised and have taken the nature of old river channels in terms of fluvial sedimentation and hydromorphology (see examples in British Military 1924; Hansman 1970). All these events have made it nearly impossible to trace the initial and older canals from the surface. ${ }^{5}$ OSL dating of their sample at the junction of Dez and the canals on the Sardarabad anticline resulted
$2370 \mathrm{BP} \pm 230$ years (Sarafi et al. 2019, p. 23). 
The study by Sarafi et al. (2019) counts at least two ancient canal networks related to Dez, one of them being Nahr-e Atiq. ${ }^{6}$ Based on their reconstruction, the authors assume that these canals were connected to the Karkheh River via the Harmushi canal (see 26, Fig. 10, and 11). Unfortunately, their suggestion regarding the Dez canals is based on only one OSL-dated sediment sample at the junction of Dez and these canals (see 22, Table 1). This is by far not sufficient for a reconstruction of the age of the canal. Considering the importance of this watercourse for understanding two prominent settlement complexes of Susiana-Abu Fanduweh and Haft Tappeh - this must be investigated in more depth.

The so-called Nahr-e Atiq ${ }^{7}$ is a slim and rather straight watercourse, starting at the approximate location $32^{\circ} 15^{\prime} \mathrm{N}, 48^{\circ} 18^{\prime} \mathrm{E}$ near the Dez river at its braided upper course, flowing south, then turning west in an $80^{\circ}$ angle and passing the Abu Fanduweh mound (archaeologically known as KS59), flowing through the Haft Tappeh site (KS98). It finally joins the Shaur river south of this site at a proximate location $32^{\circ} 02^{\prime} \mathrm{N}, 48^{\circ} 18^{\prime} \mathrm{E}$ (see Fig. 2 ).

The Food and Agriculture Organization of United Nations conducted a soil survey of the Dezful plains (northern Khuzestan) during the 1960s as preparation for a largescale project in industrial agriculture. On the map of this area, the flow of this Nahr is marked with two soil systems, eroded terrain, and a complex area of remnants of ancient canals (Veenenbos 1958, p. 20: figure 2). The geomorphologist of this project mentions this watercourse as a "deeply eroded gully" and assumes that it is of "artificial origin" (Veenenbos, 1958, 23), being "developed from ancient irrigation systems" (74). Based on soil series and related archaeological sites, he concludes that the canal was separated from the Dez river sometime between the first millennium BCE and the first half of the first millennium CE (Veenenbos 1958, p. 41).

During the mentioned project, traces of ancient watercourses between Shaur and Dez were identified and documented. These traces have been lost ever since, because of the intensive industrial agriculture of the area, since the 1960s. In these documents, Atiq is thought to be originated at about $32^{\circ} 10^{\prime} \mathrm{N}, 48^{\circ} 20^{\prime} \mathrm{E}$, adjacent to a series of these traces, flowing southwards, then braiding into three distinct arms, reaching the Haft Tappeh archaeological complex, and joining the Shaur river just south of the Haft Tappeh Ridge (Veenenbos 1958, p. 29: Figure 5). These ancient levee traces seem to belong to an older course of the Karkheh river before it changed its eastward flow to a more southerly flow sometime in the mid-Holocene (Veenenbos 1958, pp. 33-34; see Sarafi et al. 2019 for an alternative view).

$\mathrm{Atiq}^{8}$ is sometimes considered to be a branch of the Shaur river (Gaud et al. 1962, p. 237, and Carte 2); alternatively, an ancient canal from the Dez river before the construction of the Harmushi canal (Adams 1962, Fig. 4, 114; Sarafi et al. 2019, p. 30). Others suggest that it is a relic of the palaeo-Dez, which reaches Shaur, before its junction with Dez (Veenenbos 1958, p. 20: Fig. 2), or a relic of the westward migration of Karkheh during the

\footnotetext{
${ }^{6}$ Nota bene, not to confuse this small rivulet in north Susiana with the older course of the Euphrates River in south Mesopotamia, which is also called Nahr-al Atiq or Al-Furat-al Atiq. See Verkinderen (2015, pp. 41 and 251) for details to the latter watercourse.

7 Alternative name: Adtij, Attig, Persian: جى.

8 The locals call this rivulet "Nahr-e Attij". This word seems to be a destructed version of Atigh, meaning "old" in Arabic. But this is only speculation, as the name has lost its meaning throughout the ages. Here the phonetic version "Atiq" is preferred to avoid confusion.
} 
mid-Holocene (Kouchoukos 1999, pp. 98, 114). Yet, these suggestions are all speculative. ${ }^{9}$ The genesis and nature of Atiq are not fully understood. ${ }^{10}$

\section{Results}

The results of this investigation will be presented in two categories, the archaeological context of the case study, and the geoarchaeological evidence of the field survey.

\section{Archaeological context}

As mentioned above, Nahr-e Atiq flows in the direct vicinity of the archaeological sites, Abu Fanduweh and Haft Tappeh, as well as several other settlements from the Prehistory to Medieval times (see Fig. 7 for the sites). A summary description of these sites follows.

Abu Fanduweh was first documented by Adams (1962). The site is currently divided into a northern and a southern mound by Nahr-e Atiq, with ongoing heavy erosion of the mounds. The earliest occupational levels of the site belong to the Early-Middle Susiana Phase, about the beginning of the fifth millennium BCE (Alizadeh 2008, p. 14). Limited excavation has yield remains of more than fifty pottery kilns ${ }^{11}$ and materiel culture from the Proto-literate period in the northern mound and massive construction of mud bricks on the southern mound. On the highest part of the southern mound, a cemetery with two separate phases has been discovered, which was disturbed by the later occupational levels from the Late-Elamite settlement (Negahban 1991, pp. 10-11).

Abu Fanduweh is considered a major pottery producer of about 7 ha in size and a central settlement—-besides Susa and Chogha Mish—with at least five satellite settlements in the early Uruk period, at the beginning of the fourth millennium BCE (Johnson 1973, pp. 92, 96). Earlier surveys suggested that the site has expanded spatially during the Middle Uruk period. The craft production areas have been identified to be on the lower parts, and the architectural remains are on the upper parts of the site (Wright and Johnson 1985, p. 27). This spatial pattern has been consistent in the next millennia throughout the Susiana plains, especially seen in Chogha Mish and Susa.

A general decline of population is assumed in the Late Uruk, as these satellite settlements were abandoned (Johnson 1973, p. 146). A recent survey with a limited excavation on the southern mound disagreed with this hypothesis and estimated that the site was about 12 ha in the Late Uruk period (Alizadeh 2008, p. 23). The occupation might have continued through the Susa 3 phase (Alizadeh 2008, p. 25). The southern mound has been subject to a systematic survey in recent years. A high number of Late Uruk pottery in three different categories was documented. A Sasanian occupational period is also possible, although the known remains have been destroyed during the Iraq war in the 1980s (Habibi and Karami 1387/2008).

Haft Tappeh is a considerably larger archaeological site with an estimated size of 100 ha. It was documented by Admas as a historical site (Adams 1962). This mound

\footnotetext{
${ }^{9}$ R. Wenke has not identified this watercourse in his survey regarding the Parthian and Sasanian times on north Susiana (see Wenke 1976).

10 Traces of different canals corresponding to Nahr-e Atiq are documented in Fig. 6: Walstra et al. (2012). The role of rivers in ancient societies, or how man transformed the alluvial landscapes of Khuzestan (SW Iran). EGUGA, 9519 (thanks to an anonymous reviewer for pointing this out).

11 Unfortunately, these remains were destroyed by the private owner of the land in the 1990s.
} 
complex consists of several elevated mounds, which have been partly destroyed by agricultural activities and leveled for sugar cane plantations. The massive cultural remains, including a vaulted tomb with brick structures, were discovered by accident during construction work for the road in the development project of the sugar cane plantation. Subsequently, fourteen seasons of excavation have been conducted, ${ }^{12}$ which suggested that Haft Tappeh is the ancient city of Kabnak from the Middle Elamite period (Negahban 1991, 2002). The material culture, including clay tablets, pottery vessels, bronze objects, and stone stelae, indicate that the settlement was mainly occupied in the Middle-Elamite period (1500-1200 $\mathrm{BCE})$. There are indications of a fire and destruction in the excavated halls, which might have been the reason for the settlement's abandonment (Negahban 2002, p. 529; MofidiNasrabadi 2014). Based on absolute dating, this level belongs to the thirteenth century BCE (Mofidi-Nasrabadi 2004).

The most impressive remains in Haft Tappeh consist of massive terraces and halls with mud-brick construction of at least $60 \mathrm{~cm}$ thickness. Gypsum and bricks were used in the construction of another large building, probably a temple or a palace (Negahban 2002). On the southeast mounds of the complex, layers of workshops with pipelines of pottery for water transport, kilns, and material culture such as written clay tablets and bronze objects have been found (Negahban 1991).

Work on Haft Tappeh resumed starting 2001. In a series of excavations, the other remaining mounds were investigated, resulting in discovering further traces of construction levels. Based on $\mathrm{C}_{14}$ dating, four levels have been identified, ranging from the seventeenth to the fourteenth century BCE (Mofidi-Nasrabadi 2015, p. 28).

The most recent levels of occupation in Haft Tappeh belong to the Arsacid (Parthian) and Sasanian periods, where a series of pottery kilns and workshops were settled on the western extension of the mound complex (Mofidi-Nasrabadi 2004; Mofidi-Nasrabadi et al. 2010). Due to the massive construction levels of the Middle-Elamite period, it is challenging to investigate probable earlier levels at the site. Yet, a few ceramics from the early third millennium BCE were found in the last season of excavation in $2015,{ }^{13}$ supporting this possibility.

Besides these two sites, there are many known settlements and archaeological remains from the fifth millennium BCE to the Medieval times in the vicinity of the watercourse (see Fig. 7 for selected sites). Archaeological evidence suggests that the Nahr-e Atiq was not merely a recent canal. Based on his survey, Adams (1962, p. 114) suggests ${ }^{14}$ that Atiq has emerged in the Late-Elamite period (1200-640 BCE) as a canal, connecting Karkheh to Shaur and enabling the cultivation of the lands between Karkheh and Dez. He also suggests that the Harmushi-Darion-Atiq canal system has evolved into its current state during Sasanian times (Adams 1962, p. 117).

As mentioned in the methods section, the current course of the Nahr-e Atiq is visible on Google Earth imagery. By comparing this course and the suggestions of archaeologists

\footnotetext{
${ }^{12}$ Unfortunately, this archaeological project ended abruptly due to the political unrest of the 1979 revolution. Yet, thanks to this project Haft Tappeh is one of the few archaeological sites in the Ancient Near East with a Museum in situ. The second series of excavations from the university of Mainz, Germany have yield impressive results and helped shedding light on an otherwise hardly known period of the Elamite history.

13 Personal communication, Mifidi-Nasrabadi in 2015.

14 Adams does not name the canals and rightly insists that these suggestions are speculative.
} 

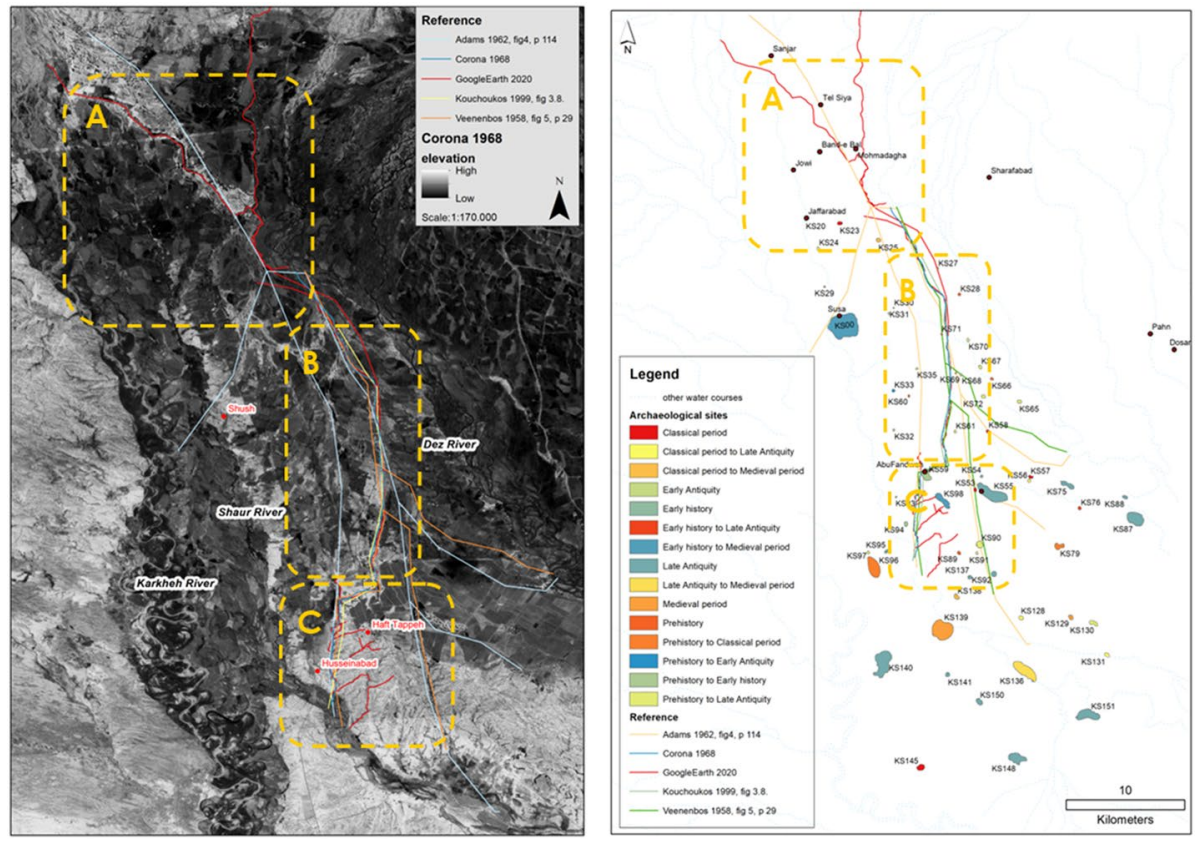

Fig. 7 Three sections to Nahr-e Atiq based on available suggestions and known sites mentioned here (illustrated by the author)

who surveyed the area in the last century-prior to the intensification of agriculture-one can identify three sections of this watercourse (see Fig. 7). ${ }^{15}$

The first section (A) stretches from the probable source of the watercourse at Pay-e Pol to the vicinity of the current Dez course, where Atiq makes a turn southwards. The second section (B) follows this turn in a straight course to the south near the site of Abu Fanduweh. From there, the third section (C) begins, where Atiq makes another turn at an $80^{\circ}$ angle and cuts through the site and follows the Sardarabad Ridge. Atiq joins the Shaur river directly south of the ridge. Sections A and B account to about $16 \mathrm{~km}$ each and section $\mathrm{C}$ is about $8 \mathrm{~km}$ long. As is visible here (Fig. 7), there are discrepancies among the sources as to the course of Atiq (see Fig. 2 for the current course of Atiq).

\footnotetext{
15 As shown in the figure, some sections of the Nahr are documented differently by different authors in their maps. This has several reasons: (i) the maps are mostly published as overview maps for archaeological reports and papers. Their aim was not to present exact lines of the watercourses, especially the less crucial ones such as Nahr-e Atiq. The author has georeferenced these maps based on the location of a few points (such as Susa, or meanders of Dez). Therefore, the generated course of the Nahr does not necessarily represent the reality of the course. The author estimates an error of about few meters in this category. (ii) During the industrial intensification of the area in the 1960s and 70s, a number of channels were corrected in their course prior to their integration in the irrigation network. A few sections of Atiq were also included in this undertaking. Furthermore, the Haft Tappeh Sugarcane plant drainage system has manipulated the Nahr in its middle course greatly. Therefore, maps before and after these corrections have documented slightly different courses for the same Nahr. The author estimates a change of up to one $\mathrm{km}$ in this category. (thanks to an anonymous reviewer for suggestion to include the explanation).
} 
Section A is significant regarding the question of water sources. There are two possible sources for Atiq, one from the Karkheh upper stream, and the other from the Dez upper stream, a few kilometers to the east. Adams (1962, p. 114, Fig. 4) identified sites in the direct vicinity of the watercourse in section A, including Sanjar and Tel Siya, which were occupied from the Early history (Susa I) to the Late Antiquity (Sasanian period). On Google Earth, two distinct courses are visible, one from Pay-e Pol and the other from the upper stream of Dez further to the north. There is no evidence connecting these two courses to the archaeological record. Yet, their sinuosity and meandering character indicate the north-south course could be natural, and the western course could be part of the Darion canal (probably dated to the Achaemenian period), or even earlier.

Two other sites are essential in comprehending section A. One of them (KS25) lies directly at the western course suggested by Adams. ${ }^{16}$ This small site has a long settlement history from the Classical to the Medieval period. The other site (KS27) lies directly on the course visible on Google Earth, as well as Corona, and suggested by Kouchoukos (1999, Fig. 3.8.) and Veenenbos (1958, p. 29, Fig. 5). This site was occupied in two different phases in the Prehistory (Susiana d) and Late Antiquity (Sasanian period) with intervals in between. As for the source of Atiq, the archaeological evidence from section A seems to indicate a change or revival from the Classical period (Early to Middle-Elamite period). Probably, Atiq has been either dug as a new canal from Karkheh or revived from a dry rivulet of Dez in the Classical period.

Section B contains a part of the Nahr-e Atiq, which is more visible and less controversial in the mentioned surveys. Besides Abu Fanduweh, there are five known sites (from north to south KS28, KS97, KS70, KS67, KS69, KS61) in close vicinity to the suggested course in section B, all dating to the Prehistory (Susiana d). Three of these sites (KS70, KS69, KS61) were reoccupied in Late Antiquity (Sasanian period). Another site (KS68) appeared at the same time (near KS69). All these sites are located on the eastern bank of the watercourse, between Atiq and Dez.

The known sites (KS30, KS31, KS35, KS33, KS60) from the western bank (between Atiq and Karkheh) date to the Prehistory (Susiana d) to the Early History (proto-literate) and Early Antiquity (Arsacian period), except for one site (KS32) which appears in Early Antiquity. This indicates a sustainable settlement system in the whole period, with an increase of reoccupation of abandoned sites in both Early and Late Antiquity. The area had probably access to a watercourse in the whole period, with a revival or increase of water supply in Antiquity. This suggestion is supported by our understanding of the large-scale projects of infrastructure in the Sasanian and Islamic times.

Section $\mathrm{C}$ is less agreed upon by our sources. The rather abrupt turn of Atiq, its cutting through the large site of Abu Fanduweh and its sudden turn to the south, make its course extremely heterogeneous. Different scholars tried to resolve these issues with proposing two different branches of the Atiq watercourse in section C. The course flowing to Abu Fanduweh corresponds to the lower course of the western canal from Admas (1962), which flows parallel to the eastern one from sections A and B. His eastern canal, which is agreed upon in section B by others as the only course, flows directly to the south. With this suggestion, he resolves the issue of the two sudden turns of the canals and presents two distinct canals flowing parallel and reaching Shaur separately, one passing by Abu Fanduweh and

\footnotetext{
${ }^{16}$ He suggested two parallel canals flowing south from Pay-e Pol. The eastern canal corresponds with the suggested courses by others. Based on the other suggestion, one can conclude that the western canal is not related to Atiq in its upper stream which is in section A (see Adams 1962, p. 114, Fig. 3).
} 
the other passing a large site (KS55) from the Late Antiquity (Late Sasanian and Early Islamic periods).

Veenenbos (1958, p. 29, Fig. 5) also suggests two branches in section C, his eastern branch corresponding with Adam's suggestion. His western branch separates from the main Atiq canal about $7 \mathrm{~km}$ north of Abu Fanduweh and keeps a sudden turn at this site. Interestingly, none of the suggestions passes Haft Tappeh with its long occupation from the Classical period (Middle-Elamite) to Late Antiquity (Sasanian period). This site (KS98) lies about $2 \mathrm{~km}$ from each of these canals. It is not clear whether one of these courses or even both supplied the Middle-Elamite city of Kabnak with water. Alternative sources of water in the direct vicinity of the site are not known.

There are six sites (from north to south KS54, KS55, KS53, KS90, KS91, KS92) at the banks of the eastern canal in section C. The top three sites (KS54, KS55, KS53) were occupied from the Early history (proto literate) and Classical period (Sukkalmah) to Late Antiquity (Sasanian and Early Islamic periods). The lower three sites (KS90, KS91, KS92) were occupied from the Prehistory to Late Antiquity, including a Sasanian fort (KS92). The two sites (KS54 and KS 91) directly at the banks of eastern Atiq were occupied in two phases, one in Prehistory and one in Late Antiquity. This can be another indication of a hydrologic change or revival of the watercourse in the Sasanian period.

This summary provided the archaeological indications of a fluvial change of this watercourse and its likely old age. Complementary evidence from a geoarchaeological investigation conducted by the author shall clarify the genesis of this Atiq.

\section{Geoarchaeological evidence}

The results of the survey and the eight cores are presented in Table 2 (for key data and Fig. 1) (for locations).

B1 is directly located on the edge of Atiq as it passes the archaeological site of Abu Fanduweh. It has the highest elevation of all boreholes. B1 contains two anthropogenic horizons (cultural debris) separated by a fluvial sediment package of well-sorted silty sand (Fig. 3). This fluvial deposit is found between 190 and $90 \mathrm{~cm}$ depth and contains thin lenses of silty clay, indicating phases of seasonally desiccated beds. Yet, this sediment cannot be interpreted further because it is profoundly affected by the erosion and mixture of cultural debris in the immediate environment of the site. At about $190 \mathrm{~cm}$ depth, another loam layer with cultural debris appears. Based on the pottery found in this sediment, ${ }^{17}$ the horizon can be dated to the late fifth millennium BCE.

B2 is placed on the western bank of the canal, near Abu Fanduweh, just a few hundred meters to the north of B1. It consists of a $4 \mathrm{~m}$ thick silty loam with lenses of reduction and turf as well as sand. This horizon is underlain by layers of loam with oxidation and ceramic. This is remarkably similar to the cultural debris of B1 and can be interpreted as such. The whole soil profile of B2 is very well sorted.

B3 is located on the east edge of Atiq, about $2.5 \mathrm{~km}$ to the northeast of Abu Fanduweh. It contains the same silty loam known from B2, which is covered by $1.5 \mathrm{~m}$ of well-sorted silty clay loam. In this horizon, a high level of bioturbation is evident. The silty loam in B3 differs slightly from the one in B2. It is finer in texture and lacks the lenses of sand.

\footnotetext{
17 Two pieces of diagnostic pottery were found. These pottery sherds are comparable to published material in Alizadeh (2008, p. 21) and no. 4, 13, 17, 22, in Habibi and Karami (2008, pp. 75-79).
} 
B4 is placed near the current arm of the Shaur river, south of the town Hosseinabad. It consists of three different horizons. Right beneath the humus topsoil lies a reduced silty loam with high organic content. This horizon changes gradually to sandy loam at $1 \mathrm{~m}$ depth. This sediment is also rich in organic content and indicates a concentration of soluble salts due to its high electric conductivity. At about $2.3 \mathrm{~m}$ depth, layers of poorly sorted sand and gravel appear.

B5 is located on an active and visible older course of the Shaur river, about $1 \mathrm{~km}$ west of B4, and about $2 \mathrm{~km}$ north of the large site Tepe Kheif (KS96), which was occupied from the Prehistory to the Classical period. B5 contains three different horizons, two of them also known from B4. The reduced silty loam changes abruptly to the poorly sorted sand and gravel layers at about $2 \mathrm{~m}$ depth. At $3.5 \mathrm{~m}$ depth, a sand layer appears, which is not documented in any of the other boreholes. This is also the lowest elevation documented by the cores. Therefore, it can be interpreted as an older fluvial occurrence before the active Shaur system.

B6 is located on the western edge of the Atiq watercourse, about $2 \mathrm{~km}$ west of Haft Tappeh and $1.5 \mathrm{~km}$ south of Abu Fanduweh. It contains two known sediment packages, a 6 m tick well-sorted silty loam, also known from B2 and B3, and a well-sorted silty clay loam, which is also documented in B3 and B8, with oxidation and lenses of compact clay.

B7 is placed on the current and active main course of the Shaur river, about $3.5 \mathrm{~km}$ west of B6. The sandy loam known as the second horizon of B4 appears here with differences such as ceramics and turf lenses. It also contains more sand than the other known horizon. Directly beneath this horizon, layers of sand and gravel appear, which are also documented in B4, B5, B7, and B8. Compared to the same horizon from B4, these sand and gravel layers show no indication of layered sedimentation or a repeated pattern of sand and gravel. They even seem assorted.

B8 is located on an older and currently buried course of Shaur river, about $2.5 \mathrm{~km}$ to the west of B7 and $3.5 \mathrm{~km}$ east of the current Karkheh course. This interesting sediment profile contains the known silty loam all the other cores, covering a package of sand with gravel, separated with a layer of silty clay loam known from B3, B6, and B7. Except, in this core, this horizon appears in connection with silty loam in the other profiles.

The placement and documentation of these sediment cores helps: (1) to characterize both Atiq and Shaur systems by their associated dominant sediment packages/units (SP1 to SP4, Table 3), and (ii) to use these sediment packages/units to understand the possible spatio-temporal relationships between them.

Based on the spatial positions of the sediment packages as well as their characteristics, two groups of fluvial sediments can be identified: (1) fluvial sediments of Atiq consisting of SP1 and SP4, (2) fluvial sediments of Shaur consisting of SP2 and SP3. A comparison of the fluvial elements of these two watercourses shows that both had a change of sedimentation, somewhere in their biography. ${ }^{18}$

SP1 seems to be the primary and current sediment regime of Atiq. Its heterogenic character indicates slight changes in water volume, particle size, and sorting. Especially the sand lenses in different depths seem to show phases of larger water volumes, probably due to the joining of upstream Karkheh and Dez waters, for example, in high precipitation

\footnotetext{
18 "Biography" has been used in recent years in material culture studies and Archaeology to describe the evolution of an artifact as a whole in its spatio-temporal context and will be used here in the same sense.
} 


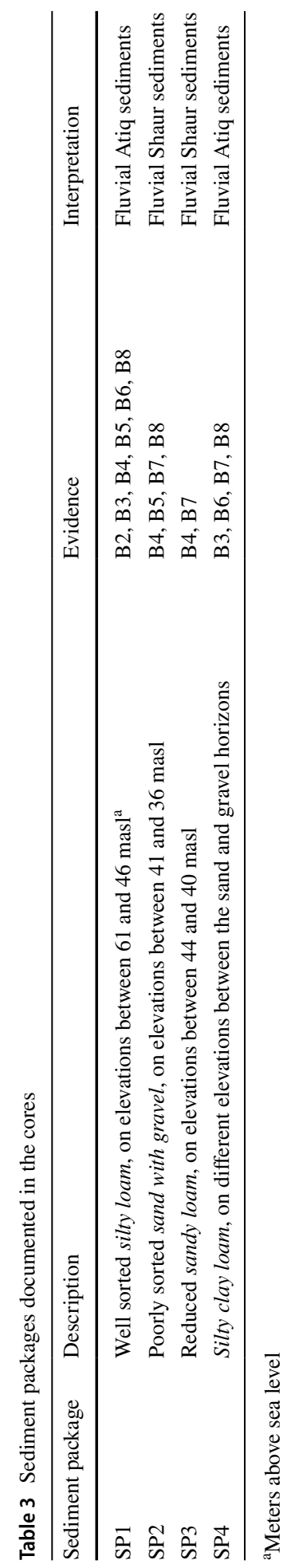


years. ${ }^{19}$ On the other hand, SP4 shows finer sedimentation of Atiq, indicating lower and slower water flow. Interestingly, this sediment is also found in B8, which lies about $6 \mathrm{~km}$ to the west of Atiq and $2.5 \mathrm{~km}$ to the west of Shaur. This can be interpreted as traces of another Nahr in relation to Karkheh, probably the third branch of the canal system suggested by Adams (see Adams 1962, p. 114: Fig. 4 and Fig. 3). Its similarities with the sediments documented in the immediate vicinity to Atiq can also support the idea of Karkheh as the current source of Atiq.

SP2 can be interpreted as a typical fluvial package of current Shaur. It is similar to the Karkheh basin, as documented by others (Motamed et al. 2016/1395). Its poor sorting corresponds to the known fluvial regime of Shaur as a highly turbulent river, with repeating cycles of sudden flood and low water flow, as reported in historical accounts (Barthold 1984; Le Strange 1873, p. 240). SP3 relates likewise to Shaur and represents the most recent sedimentation of this river. This fine-grained fluvial package is highly reduced, indicating a permanent yet low watercourse with steady sedimentation. This package lies in both B4 and B7 directly on the older package in Shaur, with a sand lens, a few centimeters thick. This indicates a shift in the fluvial regime without any remarkable hydrological events.

Comparing the fluvial packages of Atiq and Shaur, it becomes clear that they are of different genesis. While Shaur consists of typical riverine sediments with sand and gravel, sediments of Atiq contain typical packages of silty material with poor sorting. On the other hand, Shaur sediments include lenses of silt and clay — typical canal filling - and Atiq sediments include lenses of gravel without any sand horizons. These two indicate a change of fluvial regimes and an inclusion of both fluvial systems in the hydrologic regime of west Dez.

Another relevant comparison relates to the general elevation of the region, including the floodplains of East Karkheh to West Dez. Shaur and Atiq are located in between these two. The region has a general slope from the northwest to the southeast (Fig. 8).

Shaur lies much lower than Karkheh and follows the slope of the plain to reach Dez below the Sardarabad Ridge, south of Hesseinabad. On the section view crossing Shush (profile 1), Atiq has a rather narrow and shallow bed, while the same watercourse has an incised bed with a depth of at least $3 \mathrm{~m}$ on the section view of Abu Fanduweh (profile 2). In both cases, Atiq lies on a slightly higher plain than Shaur and Dez. In the section between these two profiles (corresponding with section B from Fig. 7), there are traces of older channels directly parallel to the current Atiq (Fig. 9). These traces are meandering and not straight.

Unfortunately, intensive land-use in this area hinders a complete and reliable reconstruction of these older traces of the Atiq watercourse. Yet, their existence substantiates that the current Atiq might be a younger watercourse revived from an older rivulet or dry canal. This explains the findings of gravel levels without any sand or other fluvial indication in the direct vicinity of the Atiq watercourse, as shown in several soil profiles north of Abu Fanduweh.

\footnotetext{
19 The most recent event was a flood in two phases in March and April 2019 following an unusually high precipitation year $\left(2018 / 2019,27 \mathrm{Mm}^{3}\right.$ of water instead of $\left.13 \mathrm{Mm}^{3}\right)$. This resulted in a temporal connection between Dez and Karkheh, as both rivers flooded their plains and moved their meanders.
} 


\section{Discussion: definition of Nahr}

In hydrological terms, natural watercourses and canals can be differentiated by specific elements of fluvial sediments, such as gravel beds in rivers and poorly sorted gley sediments in canals (Wilkinson 2003; Jotheri 2018). Yet, analysis of many watercourses in the region has suggested that some watercourses show characteristics of both natural and artificial courses (see below). On the other hand, historical reports indicate that an intentional manipulation and reviving of old and dry courses has taken place, especially during Late Antiquity and the Middle Ages (Barthold 1984; Verkinderen 2015). Therefore, it is necessary to define a third category for watercourses.

The utmost crucial indicator of a Nahr is that it consists of a mixture of natural and anthropogenic fluvial elements in its course. In comparison to a river or canal, a Nahr is rather heterogeneous and can be defined as a jigsaw of diverse elements from the other two categories (Fig. 10). Based on the presented geoarchaeological evidence, a Nahr can be defined as a hybrid watercourse with the following geo-characteristics:

(1) Sedimentation and texture the most prominent indicator for a river is its gravel bed. Additionally, in a river, fluvial horizons are deposited in good sorting, so that one can study the three types of water flow in a river, starting with fine sediments on the surface, sandy layers as the annual regime of perennial rivers getting coarser with depth, and finally the gravel bed at the bottom. On the other hand, gravels are missing in the sedimentation process of canals. Furthermore, canal sediments are mostly finer grained than natural fluvial sediments and are often missing entire horizons/sedimentologic sequences due to their ever-changing regimes (seasonality of water flow), and their intentional cleansing by the humans in regular intervals. A Nahr can show both these sediment regimes in correlation with their specific locations. If a sediment horizon consisting of gravels is documented in a watercourse at one point and is missing in another point of the same flow, this is a strong indication that this a manipulated canal of natural origin, e.g., a Nahr.

(2) Size and flow Nahrs are comparable to rivulets in size. If they originate from a humanmade canal, they are dug on a relatively flat surface, which ultimately affects their flow. If they have been of natural origin, they are similar to rivers in their size and flow on a slope between $0.5^{\circ}$ and $2^{\circ}$.

(3) Length and sinuosity another very telling indication of natural watercourses is their sinuosity index. ${ }^{20}$ Based on the physical laws of geomorphology, watercourses tend to follow the surface relief of their landscape and shape their course in accordance with the slope and soil texture of their setting. This means that rivers usually build more meanders with time. However, in canals, the sinuosity index of any given section shall be near factor one, unless the canal is a manipulated or revived natural course, e.g., a Nahr. Additionally, the length is decisive, as canals are dug with clear goals (transporting water from A to B) and are less lengthy than natural watercourses. Although there is no well-defined limit to be considered suitable as a differentiative measure in this regard, one can estimate that in the study area canal cannot be longer than $40 \mathrm{~km}$ and

\footnotetext{
${ }^{20}$ Sinuosity is a ratio measured in dividing the actual length of the watercourse by the distance between its source and its estuary or junction to another watercourse. The higher the index, the more meandering is a watercourse. A straight canal has an index of 1. Most rivulets have an index between 1 and 2. An old meandering river can show a sinuosity of up to over 2 .
} 


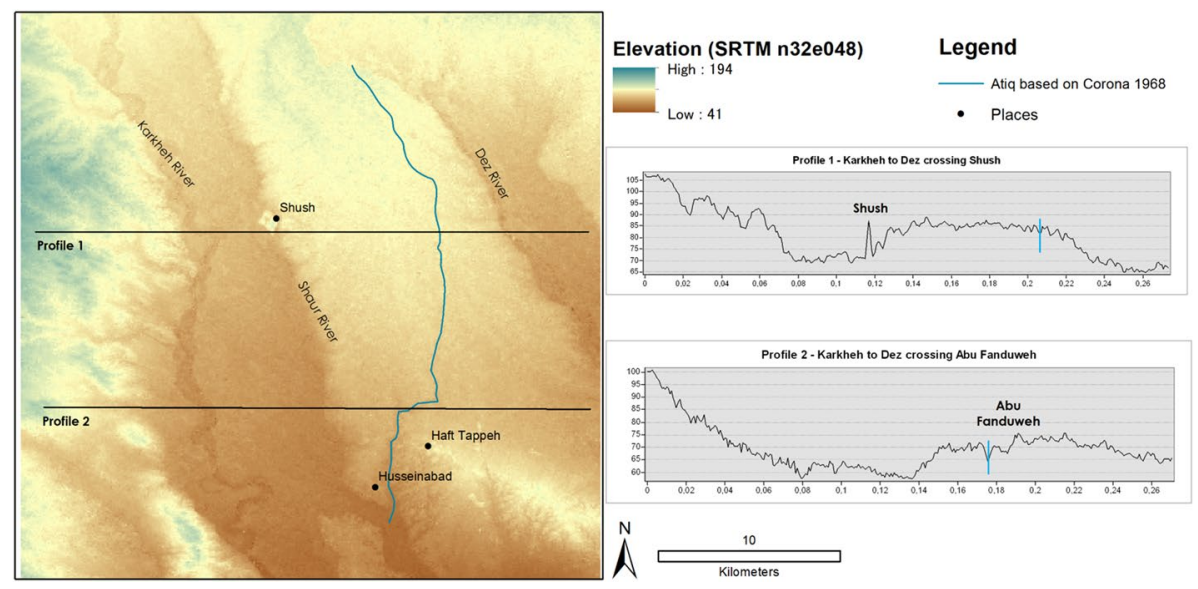

Fig. 8 Elevation of Atiq watercourse and its environs in two cross-sections; $\mathrm{x}$ axis shows distance in $\mathrm{km}$ and $\mathrm{y}$-axis shows elevation in $\mathrm{m}$ (illustrated by the author)

shorter than $5 \mathrm{~km}$, due to the specific slope and small plains, and the abundance of other water sources, whereas the existing natural rivers are between 200 and $400 \mathrm{~km}$ in length. Any watercourse with a length in between these two estimations should be investigated as a Nahr.

(4) Location in the archaeological context at least since the second millennium BCE, largescale irrigation projects are documented in the region, under the first urban developers of the ancient Near East. There are at least seventeen known canals alone in the vicinity of the ancient Susa. Their names are mentioned in the Nuzi texts from the second millennium BCE. The Middle Elamite period (1500-1100 BCE) has been a time of monumental buildings with complex water management networks in Greater Susiana. The first millennium BCE to the first millennium CE has seen three transnational empires with ambitious planning projects. The Greater Susiana has been in the center of all these projects due to its arable capacity, its connection to the Persian Gulf, and its vicinity to the Mesopotamian and East Mediterranean regions. Especially the Sasanian era $(220-650 \mathrm{CE})$ has left prominent traces on the landscape of Susiana. It is possible to identify the correlating watercourses to specific sites and settlements based on their settlement history and reconstruct the origin of the watercourse as a human-made canal or a restoration of an older stream. In this case, the current sediment regime, as well as function of a watercourse, indicates its evolution after the probable abandonment of the settlement. The canals, which continue to integrate into the natural water network and take on the fluvial elements of the landscape, will be considered as Nahr, in comparison to the ones that are only traceable of imagery as fossil watercourses.

(5) Confluences and junctions rivers in the landscape of the Greater Susiana are braided in their upper stream, consist of at least three tributaries per $100 \mathrm{~km}$, become meandering in their middle stream, and finally join each other at their downstream, and eventually reach the Persian Gulf. In between their watercourses, an extensive network of artificial canal systems has been established. Their traces are still visible at different places on older imagery. Canals transported water from rivers to other watercourses or away from 

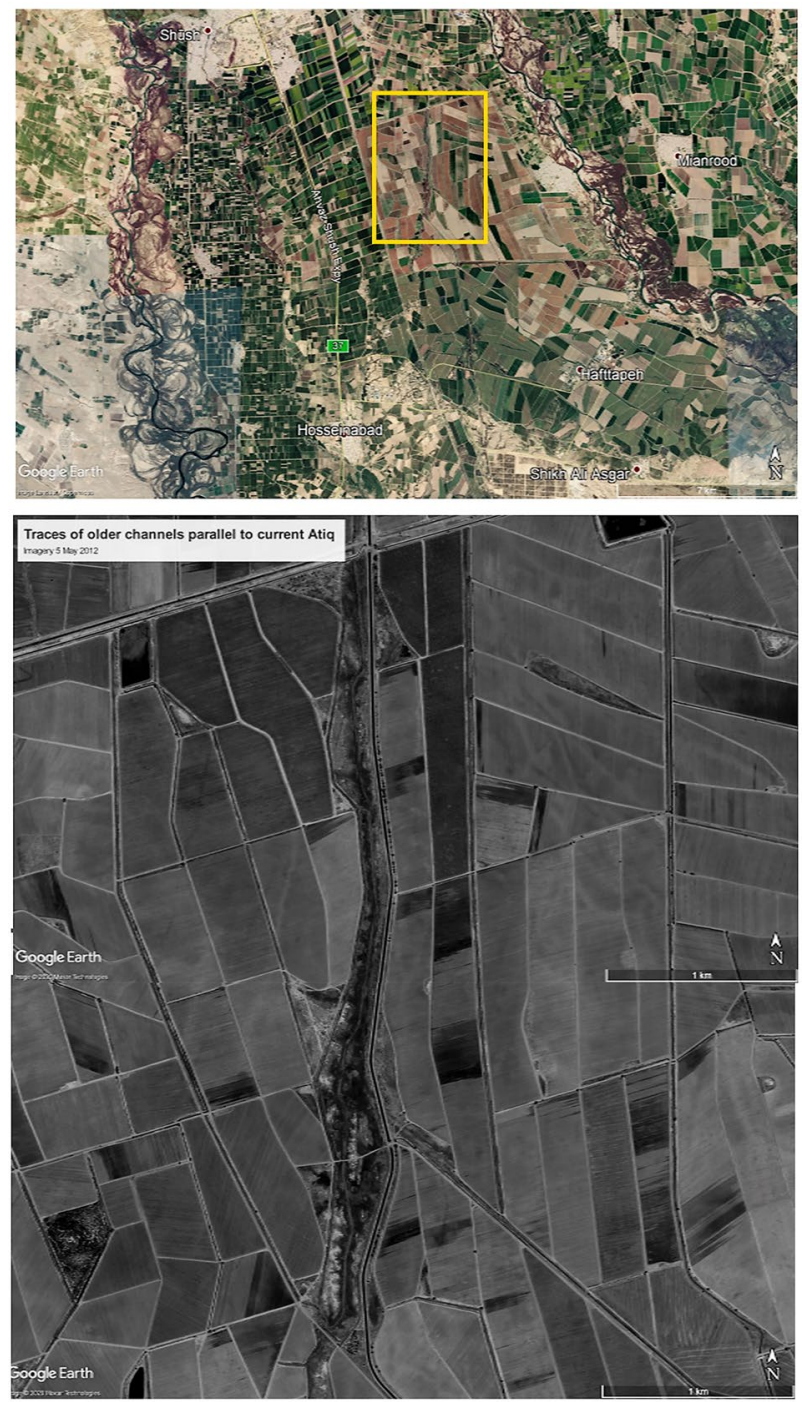

Fig. 9 Traces of older channels near the current Atiq watercourse on Google Earth ( modified by author)

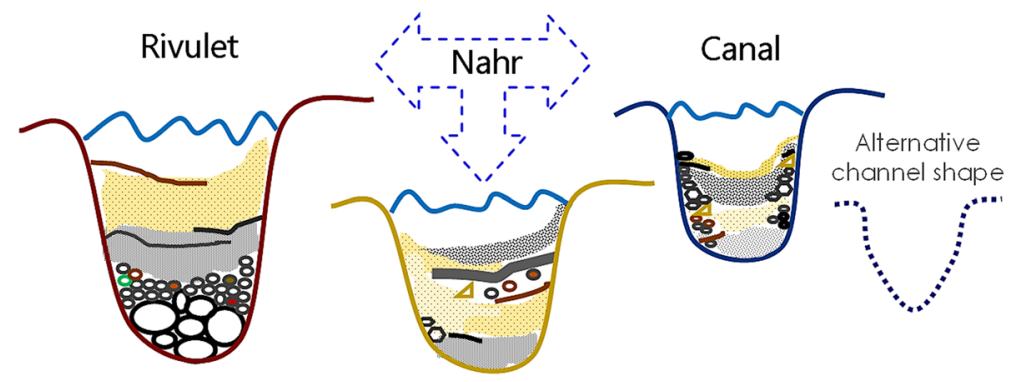

Fig. 10 Schematic view of the differences in sediment sequences among natural, artificial, and hybrid watercourses, rivulet, canal, and Nahr respectively (illustrated by author) 
the floodplain into the irrigated land. In both cases, a canal's starting point would lay higher in elevation than its ending point. If a canal is left unused for a long time, the sedimentation of the source watercourse gradually changes its flow and may even cut its connection to other watercourses or fill up its junctions to the other water networks. This is similar to the process of oxbow lakes and old meanders, yet rather stretched for the length of the watercourse. Eventually, the remaining fluvial regime will take on more natural flow and might even meander, without any confluences on its upper stream. In this case, a Nahr can be identified.

\section{Atiq as a Nahr}

Based on the elements defined in the last section, Atiq is qualified as a Nahr. Probably, Atiq underwent two periods of a functional canal, before and after the emergence of the Harmushi canal. Currently, Atiq is integrated into the active drainage network of the Haft Tappeh sugarcane plantation and carries the water from the irrigation canal system west of the Dez river-south of Susa - into the Shaur river - south of Haft Tappeh.

To summarize the indications of Atiq being a Nahr, the following statements can be made based on the five characteristics mentioned in the results section:

Considering (1), B4 is an excellent demonstration of differences between fluvial sediments of rivers and canals. It consists of both sediments identified with Shaur and Atiq, as it is located at the confluence of these two watercourses. A comparison of the texture and sorting shows that typical silty loam sediments of Atiq covered two fluvial packages known from Shaur. This indicates that the junction of Atiq and Shaur at this point is a recent one. Atiq completely lacks sand and gravel levels. Nevertheless, its sedimentation shows two packages, a finer textured silty clay loam (SP4) and a coarser silty loam (SP1). This indicates ongoing fluvial processes in this watercourse, which would not be present in a canal. Therefore, Atiq is composed of sediments with both natural and anthropogenic characteristics, e.g., a Nahr sedimentation.

Considering (2) and (3), Shaur and Atiq have both indications of anthropogenic manipulation in their course, both follow a rather straight channel and have low sinuosity. Yet, there are differences between them. Shaur has developed flood plains and terraces, while Atiq lacks these typical indications of rivulets. Another difference is the volume of the fluvial sediments of these two watercourses. Comparing B3 as a typical Atiq package and B7 as a typical Shaur package, the finer sediments of both Atiq (SP4) and Shaur (SP3) are about $1 \mathrm{~m}$ deep, while the coarser sediments of Atiq (SP1) have a volume of at least $6 \mathrm{~m}$ (see Fig. 4), and the coarser sediments of Shaur (SP2) are at least $3 \mathrm{~m}$ thick (see Fig. 6). Atiq is remarkably canal-like for a length of about $18 \mathrm{~km}$ in its main section and an average slope of $0.7 \%$. But its depth differs immensely in its lower section compared to its upper section, from hardly $1 \mathrm{~m}$ east of Shush to nearly $5 \mathrm{~m}$ near Hosseinabad (compare profiles 1 and 2 in Fig. 8). The depth of fluvial packages of at least $10 \mathrm{~m}$ indicates a long history for the watercourse, which contradicts its straight course. Therefore, it can be assumed that different sections of the current Atiq have a different genesis, making the whole watercourse a mixture of natural and artificial channels. This is another indication of the definition of Nahr. 
Considering (4), there are at least 58 known sites $^{21}$ from the Prehistory to the Medieval period in the vicinity of Atiq (Fig. 7). The archaeological record indicates two periods of increased settlement amongst these sites, the Prehistory (Late Susiana) and the Late Antiquity (Sasanian and Early Islamic periods). This is especially evident on the sites in the direct vicinity of the Atiq watercourse (KS27, KS29, KS35, KS61, KS65, KS67, KS68, KS70, KS72, KS91, KS128). Another interesting pattern shows a series of single period sites from the Early History (proto-literate and Susa 1) and Classical Period (Elamite) in the vicinity of the middle Atiq watercourse (KS23, KS53, KS54, KS57, KS76, KS98, KS145). These could be new foundations, as they are rather large sites. On the lower Atiq watercourse, most sites belong to Late Antiquity (Sasanian forts such as KS92, and Early to Middle Islamic townships such as KS56 and KS136). But prehistoric sites are present too (KS79, KS89, KS91). This complicated archaeological setting indicates several periods of possible revival and manipulation. Probably, a small and low water rivulet existed at the location of Atiq in the Prehistory, which disconnected from Dez at some point, before it was revived with a re-connection to Dez in Classical times (see section B in Fig. 7), then disconnected again and was revived with a connection to Karkheh in enlarging its upper section to the north in Late Antiquity (see section A in Fig. 7). This speculative scenario explains the differences in texture, depth, and sinuosity of the current Atiq watercourse according to its archaeological setting.

Considering (5), the last section of the Atiq watercourse prior to its junction with Shaur shows indications of meanders. ${ }^{22}$ The meandering character of the otherwise straight and canal-like Atiq is strikingly similar to Shaur at this point. This can indicate that the original Atiq canal has taken over the Shaur meanders at some point, probably leading to their junction. Traces on Google imagery show older sections of straighter watercourses reaching Shaur at this point about $300 \mathrm{~m}$ to the northwest of the current junction, directly at the south of the Hosseinabad township. This entangled canal and river characteristics are a definite indication for a Nahr.

Nahr-e Atiq has been presented here as one case study for this new definition of a hybrid watercourse. Other candidates in the region are Gargar (eastern corridor), Shaur (north Susiana), Odjirub (central Susiana), Bamanshir (Abadan), and Shirin (Behbahan plains). Future geoarchaeological investigations can bring light to their genesis and biography as probably hybrid watercourses, clarifying their phases of interaction with their relevant settlement systems.

\section{Concluding remarks: biography of a Nahr}

This paper aimed to define a third type of watercourses-besides rivers and canalswhich should be considered and identified in the archaeological setting of the Ancient Near East. Based on the author's fieldwork in southern and southwestern Iran, this third type-Nahr-is central to the settlement pattern and its spatial evolution, especially during early historical times to Late Antiquity. Additionally, it is crucial concerning the site formation processes in the timespan between the abandonment of the site and its reconnaissance by the archaeological investigation. Therefore, it is of utmost priority to comprehend

\footnotetext{
${ }^{21}$ Most of these sites have been identified by Adams (1962), Johnson (1973), and Wenke (1976). Unfortunately, several known sites have fallen victim to intensive agricultural activities since then.

22 The locals call this section of Atiq "Rudkhane-ye Atij" (= the Atij River).
} 
the nature of Nahrs and reconstruct their biography prior to any interpretation of settlement patterns. One should understand the biography of a Nahr as a whole, while keeping in mind that it consists of different sections with probably different genesis and biographies.

There are two possible triggers for the emergence of a Nahr: either one constructs a canal from scratch, or one manipulates an existing active watercourse or revives a dried watercourse - normally a rivulet—by intentionally altering its course, flow, slope, or bed depth. In both cases, the watercourse will be integrated into the existing riverine network, and therefore open to being influenced by elements of water flow, sediment load, and climate change. Additionally, Nahrs are subject to tectonic or geomorphological events, or further anthropogenic interventions, in the same way as rivers and canals are affected. At least after 30 years (see the lower part of Fig. 2 for examples of younger canals in the Haft Tappeh sugarcane plantation), such a connection leaves traces in the sedimentation and water regime of these watercourses.

Watercourses are crucial geo-factors in the evolution of settlement systems. Their biographies must be studied and understood prior to comprehending their respective settlement systems. This fact is even more pivotal regarding past settlement systems. The first step to reconstruct the biography of a watercourse is to categorize it and to trace its genesis. Is it a natural element or a human-made structure? The example of Nahr-e Atiq shows that the third specific type of watercourse in the Near East, the hybrid Nahr, can be identified based on its spatial elements using geoarchaeological evidence. Nahrs are not rivers, for they have not emerged as a consequence of tectonic movements and hydrogeological evolution of the landscape. Nahrs are not canals either, for their current shape was not planned for specific goals, formed by humans and their tools. Nahrs have inherited characteristics from both natural and anthropogenic processes (Fig. 10). They are hybrids, products of the human-environment interaction. Nahrs are archaeological artifacts. Therefore, they have to be considered and studied archaeologically.

Acknowledgements The fieldwork of this study was funded by the German Research Foundation in 2014 (DFG GRK 1576). The author conducted the laboratory analysis at the geographical Laboratory of Goethe University Frankfurt in 2015. The author is grateful for the cooperation and support of the Iranian Center for Archaeological Research (ICAR) in Tehran and local authorities in Khuzestan. The author wishes to thank two anonymous reviewers for their valuable comments and suggestions.

Funding Open Access funding enabled and organized by Projekt DEAL.

Open Access This article is licensed under a Creative Commons Attribution 4.0 International License, which permits use, sharing, adaptation, distribution and reproduction in any medium or format, as long as you give appropriate credit to the original author(s) and the source, provide a link to the Creative Commons licence, and indicate if changes were made. The images or other third party material in this article are included in the article's Creative Commons licence, unless indicated otherwise in a credit line to the material. If material is not included in the article's Creative Commons licence and your intended use is not permitted by statutory regulation or exceeds the permitted use, you will need to obtain permission directly from the copyright holder. To view a copy of this licence, visit http://creativecommons.org/licenses/by/4.0/.

\section{References}

Adams R (1962) Agriculture and urban life in Early Southwestern Iran. Science (New Series) 136(3511):109-122 
Alizadeh A (2008) Chogha Mish II. The development of a prehistoric regional center in lowland Susiana, southwestern Iran: final report on the last six seasons of excavation, 1972-1978. Oriental Institute publications 130. Oriental Institut, Chicago

Alizadeh A, Kouchoukos N, Wilkinson T, Bauer A, Mashkour M (2004) Human-environment interactions on the Upper Khuzestan Plains, Southwest Iran. Recent investigations. Paléorient 30:69-88

Barthold V (1984) An historical geography of Iran; translated by S. Soucek. Princeton University Press, Princton, N.J.

Bosworth C, Burton Page J (2012) Nahr. In: Bearman P, Bianquis Th, Bosworth CE, vanDonzel E, Heinrichs WP (eds) Encyclopaedia of Islam, 2nd edn.

British Military India Office (1924) Military report on 'Arabistan (Area No. 13) British Library: India Office Records and Private Papers, Qatar Digital Library

Ehlers E (2011) Karkheh River. Encyclopædia Iranica XV/6:583-585

Gasche H (2005) The Persian Gulf shorelines and Karkheh, Karun and Jarrahi rivers: a geo-archaeological approach. A joint Belgio-Iranian project. First progress, report part 2. Akkadika 126:1-45

Gaud J, Arfaa F, Zeini A (1962) Observations sur la biologie de bulinus truncatus au khouzistan (Iran). Ann Parasito Hum Et Comp 37(3):232-275

Habibi A, Karami M (1387/2008) Sofale Uruk bar payeye barassi raveshmand navari tappeh jonubi Abufanduwa, Khuzestan. Payam-e Bastanshenas 5(10):63-88

Hansman J (1970) Urban settlement and water utilization in South-Western Khuzistan and South-Eastern Iraq from Alexander the Great to the Mongol Conquest of 1258, vol I. School of Oriental Studies, University of London, London

Heyvaert V, Walstra J, Verkinderen P (2010) Reconstructing landscape evolution in the Lower Khuzestan plain (SW Iran): integrating imagery, historical and sedimentary archives. In: Cowley D, Standring A, Abicht M (eds) Landscapes through the lens: aerial photographs and historic environment. Oxbow Books, Oxford and Oakvile, pp 111-128

Johnson GA (1973) Local exchange and early state development in southwestern Iran. Anthropological papers no. 51. Oriental Institut Chicago Univ., Ann Arbor

Jotheri J (2018) Recognition criteria for canals and rivers in the Mesopotamian floodplain. In: Zhuang Y (ed) Water Societies and Technologies from the Past and Present. UCL Press, London, pp 111-126

Kouchoukos N (1999) Landscape and social change in late prehistoric Mesopotamia. Dissertation, Yale University

Kirkby M (1977) Land and water resources of the Deh Luran and Khuzestan Plain. In: Hole F (ed) Studies in the archaeological history of the Deh Luran Plain: the excavation of Chagha Sefid. Univ. Chicago Press, Ann Arbor, pp 251-288

Le Strange G (1873) The lands of the Eastern Caliphate: Mesopotamia, Persia, and Central Asia from the Moslem conquest to the time of Timur, New York

Lees G, Falcon N (1952) The geographical history of the Mesopotamian Plains. Geogr J 118(1):24-39

Mofidi-Nasrabadi B (2004) Archäologische Untersuchungen in Haft Tape (Iran). AMIT 35-36:225-239

Mofidi-Nasrabadi B (2014) Vorbericht der archäologischen Ausgrabungen der Kampagnen 2012-2013 in Haft Tappeh (Iran). Elamica 4:67-168

Mofidi-Nasrabadi B (2015) Ergebnisse der C14-Datierung der Proben aus Haft Tappeh. Elamica 5:7-36

Mofidi-Nasrabadi B, Prechel D, Vahidzadeh R (2010) Vorbericht der archäologischen Ausgrabungen der Kampagnen 2005-2007 in Haft Tappeh (Iran). Deutsches Archäologisches Institut, Münster

Moghaddam A (2012) Southwestern Iran (Ch. 27). In: Potts D (ed) A companion to the archaeology of the ancient Near East. Willey-Blackwell, New York, pp 512-530

Motamed R, Saffari A, Sardari A, Bajurmand B (2016/1395) The role of geomorphologic processes on the archaeological site of Sanjar [naghshe farayandhaye geomorfologi bar mohavateye bastanie sanjar]. Jondisahpur Q [Faslnameye jondishapur] 7:41-57

Negahban E (1991) Excavations at Haft Tepe, Iran. Philadelphia University Museum of Archaeology and Anthropology Monograph 70

Negahban E (2002) Haft Tepe, Encyclopedia Iranica vol XI. Fasc 5:526-530

Sarafi A, Karam A, Saradari A, Saffari M, Motamed R (2019) Geo-Archaeology of West Susiana plain with an analysis of hydraulic structure. J Res Archaeom 5(1):17-29 (Persian with English abstract)

Veenenbos J (1958) Unified report of the Soil and land classification of Dezful Project, Khuzistan Iran. FAO, Tehran

Verkinderen P (2015) Waterways of Lower Iraq and Khuzistan. Changing Rivers and Landscapes in the Early Islamic Middle East, I.B. Tauris, London

Walstra J, Heyvaert V, Verkinderen P (2012) The role of rivers in ancient societies, or how man transformed the alluvial landscapes of Khuzestan (SW Iran). EGUGA, 9519 
Wenke R (1976) Imperial investments and agricultural developments in Parthian and Sassanian Khuzestan:150 BC to AD 160. Mesopotamia 10-11:31-157

Wilkinson T (2003) Archaeological landscapes of the Near East. Univ. Arizona Press, Tucson

Wilkinson T (2012) Introduction to geography, climate, topography, and hydrology (Ch 1). In: Potts D (ed) A companion to the archaeology of the ancient Near East. Wiley-Blackwell, New-York, pp 3-26

Woodbridge K (2013) The influence of Earth surface movements and human activities on the River Karun in lowland south-west Iran. Dissertation, Kingston: University of Hull

Wright H, Johnson G (1985) Regional perspectives on Southwest Iranian state development. Paléorient 11(2):25-30

Publisher's Note Springer Nature remains neutral with regard to jurisdictional claims in published maps and institutional affiliations.

Elnaz Rashidian is a geoarchaeologist, based in Frankfurt Germany. She has studied Iranian Archaeology in Tehran (B.A., Iran), Prehistory and Geoarchaeology in Marburg (M.Sc., Germany), and Archaeology of the Ancient Near East in Frankfurt (PhD, Germany). Her interdisciplinary research focuses on the human-environment interaction regarding the settlement patterns of the Holocene. She has participated in excavations in Iran, Turkey, Austria, and Germany in the last fifteen years, working in international multidisciplinary projects. Currently, she works as a pos-doc researcher on two separate projects (Konstanz and Marseille) concerning the environmental aspect of the Sasanian urbanization in south Iran. Her main interests are the water harvesting strategies from the Late Bronze Age to the Late Antiquity. 